attributes the large number of beads found here to trading activities attracted by the opal mines, and, tentatively, suggests 4000 B.c. as a possible date.

\section{Plastics and the Glass Industry}

IN his address to the Fifth Glass Convention held last week at Droitwich under the presidency of $\mathrm{Mr}$. H. S. Williams-Thomas, Dr. V. E. Yarsley stressed the view that plastics are not to be regarded as substitutes for the older materials, glass, wood and metals. Much of the work done on the new transparent plastic materials such as the methacrylate and polystyrol products has been inspired by glass. In aircraft construction, where low weight must combine with security and good optical properties over a wide range of temperature conditions, 'organic glass' has no rival. The technique of the manipulation of these materials has progressed very considerably, but, as was brought out in discussion afterwards, not sufficiently to enable a bottle, for example, to be blown from a plastic mass in the manner in which molten glass is manipulated by fully automatic machinery. Much interest was aroused by the reference by Dr. A. Caress to the optical and other properties of materials of the 'Perspex' type, and Drs. W. M. Hampton and J. C. Peddle pointed out the tremendous range of optical properties furnished by the optical glass manufacturers to comply with the requirements of the instrument makers, and the need for both homogeneity and very precise annealing. It appears that as yet the only serious competition that might be feared in this field is in the manufacture of ophthalmic lenses, and mass-produced lenses of the type used in very cheap cameras.

\section{"Frustration of Science" Exhibition}

THE Scientists' Section of the Left Book Club held an exhibition on May 17-22 at the Unity Theatre, Goldington Street, N.W.1, illustrating "The Frustration of Science". Charts, pictures and select quotations illustrated the contrast between science as a constructive force in society and science as a weapon of destruction, science as a means towards arousing and satisfying communal needs and science merely as an instrument for profit. Side by side with evidence of the increasing concentration on productivity from the soil was shown the destruction of commodities and foodstuffs. Alongside the figures showing the multiplication of productivity was widespread evidence of malnutrition and scarcity. The meagre sum spent on health research was contrasted with that devoted to investigations in chemical warfare; and the repression of scientific work and the destruction of scientific opportunity in Fascist countries were pointedly illustrated. Comparative graphs showed the speed-up in production that follows from rationalization, and the lag that exists between this and the index of wage rates. In the advertising of fictitious remedies for all kinds of diseases, approximately $£ 3,000,000$ per annum is spent, as compared with $£ 139,000$ per annum expended from Government sources on medical research in Great Britain. A total retail turn-over of these remedies amounts to $£ 20,000,000$ per annum.
The exhibition was opened by Prof. P. M. S. Blackett, who dealt with the historical factors that called science into being, and underlined how these same forces were now frustrating it. In discussing the treatment of scientific men in Fascist countries, he stressed its blindly reactionary character, its penalization of scientific workers in the first instance and, in the drive towards war, how later it had become essential to reverse that policy, in order to regain military and aerial efficiency. It was not, he considered, the task of men of science to solve these problems by their action alone, any more than they had alone called this situation into being; but it was their duty to discard their scientific aloofness and to bring their special knowledge and understanding to bear on these social issues in order to show, in terms of social forces, how the present situation had arisen, and so to discover a way out.

\section{Trans-Atlantic Steam Navigation}

Is connexion with the recent commemoration of the centenary of the inauguration in 1838 of transAtlantic steam navigation, an article on which appeared in our issue of March 26, p. 540, Mr. J. W. Morgan, of Springfield, Ohio, has directed our attention to the voyage from Nova Scotia to England in 1833 by the Canadian-built steam vessel Royal William. The performance of this vessel led the Canadian Government in 1895 to place a commemorative tablet on the walls of the Parliament Buildings in Ottawa, on which she is referred to as "The First Vessel to Cross the Atlantic by Steam Power . . . The Pioneer of Those Mighty Fleets of Ocean Steamers by which Passengers and Merchandise of all Nations are now Conveyed on Every Sea through. out the World". The Royal William, of about 800 tons and 200 horse-power, left Pictou on August 17, 1833, and arrived off Cowes, Isle of Wight, nineteen days later. It has sometimes been stated that she crossed under steam power alone, but that statement cannot be substantiated. As Engr.-Capt. Smith was careful to point out in his lecture at the Science Museum on March 16, every steamship both before, and long after 1838, was fitted with sails and made the fullest possible use of the wind. Indeed it is quite impossible to say with certainty what vessel first crossed the Atlantic by steam power alone. The Atlantic had been crossed by the steamers Rising Star, Curaço and Savannah before the Royal William made the passage, but their voyages, like hers, had nothing to do with a considered scheme for a regular service. The true significance of the events of 1838, the year which saw the Atlantic crossed and recrossed by the Sirius, Great Western, Royal William $I I$ and Liverpool, lies in the fact that they were the first vessels placed on the run with the idea of maintaining regular communication between Great Britain and the United States by steam in all weathers and at all times of the year. Of the four ships, it was the Great Western which unmistakably demonstrated the feasibility of the project. She was the true forerunner of our modern Atlantic liners. 